\title{
MAKNA RUANG KAMPUNG KAUMAN YOGYAKARTA DAN SEMARANG BERDASAR KONSEP RELASI DALAM PANDANGAN JAWA
}

\author{
Catharina Dwi Astuti Depari ${ }^{1}$ dan Amos Setiadi
}

Diterima : 20 Maret 2014 Disetujui: 30 Mei 2014

\begin{abstract}
Pandangan hidup merupakan seperangkat nilai yang mempengaruhi seluruh sistem kehidupan penganutnya. Dalam konteks masyarakat Jawa, salah satu konsep keyakinan yang merefleksikan pandangan hidup setempat adalah perlunya memelihara relasi yang harmonis antara pribadinya sebagai manusia dengan dirinya sendiri, masyarakat, alam maupun dengan Tuhan. Nilai-nilai keyakinan tersebut diekspresikan secara simbolis melalui desain ruang tinggal pada setiap skala ruang arsitektur. Sebagai permukiman Islam historis, Kampung Kauman menghadapi sejumlah tantangan khususnya dalam upaya memelihara keberlangsungan budayanya. Berkaitan dengan Kampung Kauman Yogyakarta, sejarah perkembangannya tidak terlepas dari pengaruh Sultan sedangkan perkembangan Kampung Kauman Semarang lebih ditentukan oleh besarnya pengaruh dari aktivitas perdagangan di sekitar kampung. Penelitian bertujuan untuk mendukung pelestarian terhadap karakteristik kampung Kauman sebagai satu entitas pribadi bernilai historis. Sasaran penelitian adalah mengungkap bagaimana pandangan Jawa dimanifestasikan ke dalam struktur ruang kampung termasuk faktor-faktor yang mempengaruhi perbedaan karakteristik antara kedua wilayah objek studi. Dalam rangka mencapai tujuan penelitian, digunakan pendekatan fenomenologi dengan metode analisis sinkronik sehingga makna simbolis masing-masing ruang Kampung Kauman sebagai artifak budaya, dapat diungkap secara detail dan objektif.
\end{abstract}

Kata kunci: pandangan hidup, konsep relasi, struktur ruang, makna simbolis

\section{Pendahuluan}

Pandangan hidup atau sistem keyakinan merupakan seperangkat nilai yang mempengaruhi seluruh sistem kehidupan penganutnya yang antara lain mencakup pola pikir dan perilaku, kekerabatan dan etika sosial termasuk ragam ekspresi dalam estetika. Pandangan hidup pada hakikatnya ditujukan untuk menjawab berbagai persoalan yang berkaitan dengan hidup, maupun yang berkaitan dengan kebenaran, kebajikan dan Tuhan (Ronald, 1988;39). Tidak hanya mencakup pola pikir, pandangan hidup menjangkau pula masalah kehendak, hati dan iman (Poedjawinata dikutip oleh Ronald, 1988:39-40). Pandangan hidup dalam kesusasteraan Jawa disebut kejawen yang dalam perkembangannya telah bercampur dengan wejangan atau petuah yang diyakini bersumber dari ilmu kebatinan. Pandangan hidup masyarakat Jawa berpusat pada konsep relasi yang terjalin antara dirinya sebagai sebuah pribadi dengan orang lain, alam maupun dengan Tuhan. Hal tersebut direfleksikan ke dalam budaya bermukim Jawa, baik pada skala mikro, mezzo maupun makro. Sejak periode Hindu Buddha, berbagai konsep keyakinan telah

\footnotetext{
${ }^{1}$ Jurusan Arsitektur, Fakultas Teknik, Universitas Atma Jaya Yogyakarta
} 
mengakar kuat dan mempengaruhi tradisi budaya Jawa, misalnya melalui upacara sesajen sebagai ungkapan rasa hormat terhadap arwah leluhur. Selanjutnya, Islam muncul sebagai satu kekuatan budaya yang kemudian mendominasi dan mempengaruhi hampir seluruh aspek kehidupan masyarakat Jawa (Ronald, 1988). Dalam sistem kekerabatan masyarakat Jawa, dikenal adanya pembedaan antar kelompok sosial berdasarkan pada status, derajat, jabatan atau golongan. Hirarki dalam sistem kekerabatan bertujuan untuk mengatur peran setiap individu dan kelompok sehingga tercipta keharmonisan dalam tatanan kehidupan sosial.

Dalam tatanan kota-kota tradisional Jawa, keberadaan Kauman menjadi bukti penting dari berlangsungnya proses sinkretisme antara budaya Jawa dengan Islam. Kampung Kauman merupakan daerah permukiman para santri yang diyakini telah berkembang sejak masa Kerajaan Demak dan Mataram Islam (Wijanarka, 2000:26). Selain faktor agama, pola penataan ruang kampung Kauman sangat dipengaruhi pula oleh kebijakan politik penguasa. Hal tersebut dapat diamati pada kasus Kampung Kauman Yogyakarta yang sejarah perkembangannya sangat ditentukan oleh peran Sultan sebagai penguasa Kraton. Berbeda dengan kampung Kauman Yogyakarta, Kampung Kauman Semarang cenderung bersifat dinamis mengalami perubahan sebagai akibat dari pengaruh aktivitas perdagangan yang berkembang di sekitar Pasar Johar dan Pasar Ya'ik. Kesamaan karakteristik antara kampung Kauman Yogyakarta dan Semarang ditentukan oleh adanya sejumlah elemen lokal yang bercirikan Islam, seperti Masjid, musholla, pondok pesantren dan madrasah. Menghadapi fenomena globalisasi, ancaman terhadap keberlangsungan karakteristik ruang Kampung Kauman semakin besar sehingga penelitian ditujukan untuk mendukung pelestarian terhadap karakteristik Kauman sebagai satu entitas pribadi historis dalam tatanan ruang kota Jawa. Sedangkan sasaran penelitian adalah mengungkap bagaimana pandangan Jawa mengenai konsep relasi manusia dimanifestasikan ke dalam ruang kampung Kauman termasuk faktor-faktor yang mempengaruhi karakteristik kedua kampung. Dalam rangka mencapai tujuan penelitian, digunakan pendekatan fenomenologi dengan metode analisis sinkronik dan deskriptif-kualitatif sehingga makna simbolis masingmasing ruang Kampung Kauman dapat diungkap secara detail dan objektif.

\section{Metodologi}

Penelitian menggunakan paradigma fenomenologi dengan pendekatan sinkronik guna memahami karakteristik ruang Kampung Kauman Yogyakarta dan Semarang. Interpretasi objektif terhadap struktur ruang kampung didasarkan pada pemahaman terhadap konsep relasi menurut pandangan Jawa. Terdapat 4 tahap penelitian, yaitu:

1. Tahap Persiapan, yaitu menyusun daftar pustaka, mempersiapkan alat dan instrumen penelitian dan melakukan kegiatan pra-survey ke lapangan.

2. Tahap Pengumpulan Data, yaitu melakukan observasi terhadap kondisi eksisting kampung dan wawancara dengan narasumber lokal.

3. Tahap Analisis, yaitu mengidentifikasi karakteristik ruang kampung Kauman, perbedaan karakteristik antara struktur kampung Kauman Yogyakarta dan Semarang serta faktor yang mempengaruhinya.

4. Tahap Kesimpulan, mencakup karakteristik struktur ruang kampung Kauman, perbedaan karakteristik antara struktur ruang kampung Kauman Yogyakarta dengan Semarang dikaitkan dengan pandangan Jawa dan faktor-faktor yang mempengaruhi perbedaan karakteristik kampung Kauman Yogyakarta dan Semarang dikaitkan dengan pandangan Jawa. 


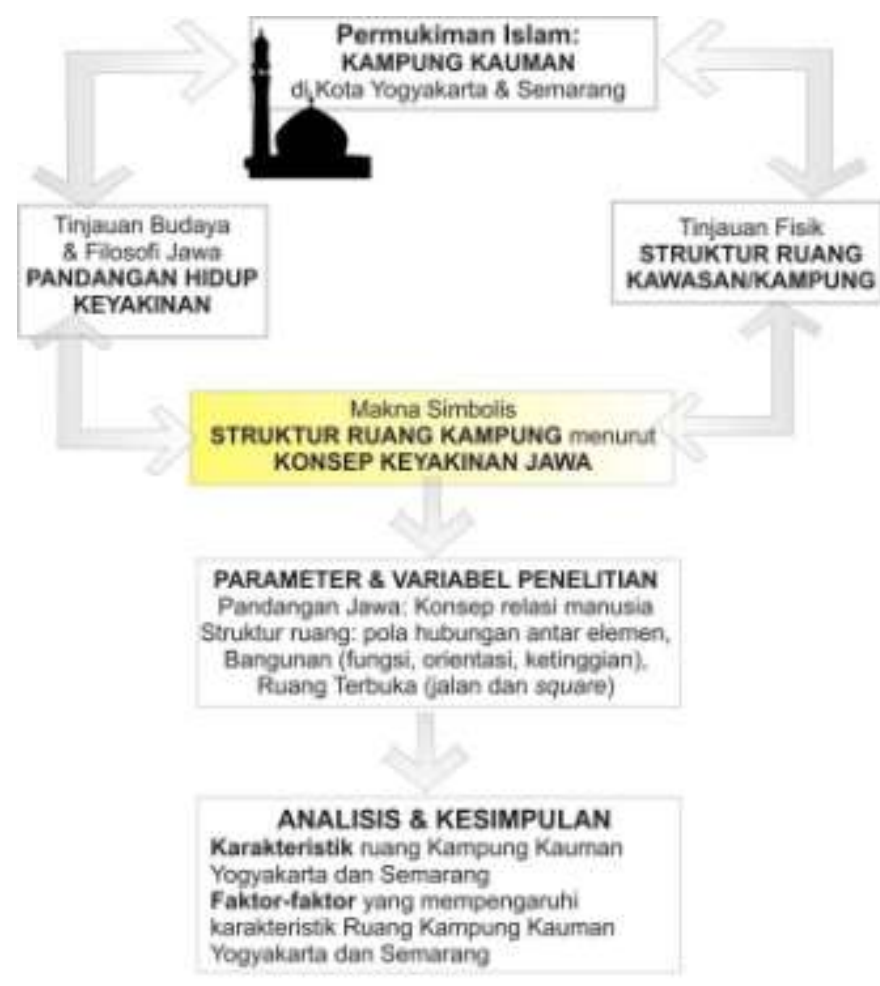

Sumber: Peneliti, 2013

\section{Gambar 1. Alur Pikir penelitian}

\section{Analisis}

Menurut Bosselman (2008) bahwa budaya kota pada hakikatnya merupakan manifestasi dari berbagai kumpulan sejarah sehingga untuk dapat memahami pola struktur ruang kota dibutuhkan pengetahuan mengenai faktor-faktor yang mempengaruhi lahirnya pola tersebut (Urban Transformation, 2008:197). Penelitian akan mengungkap karakteristik struktur ruang kampung Kauman Yogyakarta dan Semarang dalam kaitannya dengan konsep relasi menurut pandangan Jawa. Pada konteks masa kini, struktur ruang kampung Kauman Yogyakarta dan Semarang dapat dikategorisasikan berpola hibrida namun dengan tingkat kompleksitas yang berbeda, sesuai dengan orientasi keyakinan/pandangan hidup setempat dan ragam aktivitas budaya yang diwadahi. Pandangan hidup akan mengalami kristalisasi dalam setiap pribadi manusia dan akan diekspresikan melalui berbagai corak ragam budaya sehingga akhirnya melahirkan suatu wadah ruang dengan karakteristik spesifik.

Tabel 1. Konsep relasi manusia dalam pandangan Jawa

\begin{tabular}{|l|l|l|l|}
\hline \multicolumn{1}{|c|}{$\begin{array}{c}\text { Konsep Relasi dalam } \\
\text { Pandangan Jawa }\end{array}$} & \multicolumn{1}{c|}{ Sifat Relasi } & \multicolumn{1}{c|}{ Jenis Kegiatan } & \multicolumn{1}{c|}{ Fungsi Ruang } \\
\hline Manusia - Tuhan & Spiritual & Ritual/tirakatan & Ruang sakral \\
\hline Manusia - Alam & Merti kampung & Produksi & Ruang terbuka/alam \\
\hline Manusia - Masyarakat & Interaksi sosial & Sosial Budaya & Ruang komunal \\
\hline Manusia - Pribadi & Pribadi/keluarga & Praksis & Ruang privat \\
\hline
\end{tabular}

Sumber: Peneliti, 2014 
Berdasarkan tabel 1, dapat diamati bahwa konsep relasi dalam pandangan Jawa dapat dibagi menjadi empat bagian, yaitu relasi antara manusia dengan Tuhan yang diwujudkan ke dalam ruang sakral, relasi antara manusia dengan alam yang diwujudkan ke dalam ruang terbuka, relasi antara manusia dengan masyarakat sekitar yang diwujudkan ke dalam ruang komunal serta relasi manusia dengan pribadinya yang diwujudkan ke dalam ruang pribadi. Masyarakat Jawa memiliki keyakinan pula bahwa seluruh perbuatannya selama hidup di dunia akan dipertanggungjawabkan di dunia akherat kepada Tuhan Yang Maha Esa sehingga simbol-simbol yang hadir di dalam kehidupan bermukim masyarakat Jawa dapat disimpulkan tidak sekadar sebagai ekspresi estetika belaka, namun berfungsi untuk mengingatkan manusia akan peran dan tanggungjawabnya secara moral. Untuk memenuhi kewajiban hidupnya, masyarakat Jawa harus melakukan kebajikan secara nyata yang menyangkut adat istiadat, pergaulan sosial, kerukunan, musyawarah dan wahyu (Magnis-Suseno dikutip oleh Ronald, 1988:31-32). Adat istiadat merupakan segala sesuatu yang mencakup tradisi dalam keluarga atau desa yang secara konkret diwujudkan dalam bentuk ungkapan normatif, kebiasaan, upacara tabu, dan kegiatan gotong royong. Pergaulan sosial mencakup tata krama, kerukunan sebagai prinsip dalam hidup bermasyarakat dan musyawarah sebagai bentuk cara pengambilan keputusan terhadap suatu permasalahan tertentu. Wahyu merupakan wujud kebajikan yang berhubungan dengan panggilan untuk mengemban tugas tertentu yang menuntut sikap moral tertentu. Pada hakikatnya, berpandangan hidup merupakan perpaduan antara rasio dengan seluruh kepribadian sehingga filsafat mencakup tidak hanya pada pola pikir tetapi juga pada seluruh aspek kehidupan yaitu kehendak, hati dan iman (Poedjawinata dikutip oleh Ronald, 1988:39-40). Dalam tataran spasial, masyarakat Jawa tidak pertama-tama melihat wilayah dalam batas-batas fisik namun menjangkau dimensi kosmologi yang melampaui batas pemahaman manusia (Wiryomartono, 1995:30). Masyarakat Jawa memiliki keyakinan bahwa alam mikrokosmos adalah perwujudan, pengejewantahan atau representasi dari dunia makrokosmos. Dalam dunia mikrokosmos, kraton dianggap sebagai model tiruan dari dunia makrokosmos atau kerajaan surgawi. Sedangkan konsep manunggaling kawula lan Gusti dimanifestasikan ke dalam relasi antara manusia dengan alam, masyarakat sekitar dan Tuhan sehingga secara tidak langsung tata wilayah dan tata bangunan Jawa lebih mengutamakan kelangsungan hidup secara kosmis dibandingkan kenikmatan duniawi (Setyowati, 2007:199). Secara spasial, pola konsentrik pada kota-kota Jawa dibentuk oleh adanya kraton sebagai titik pusat yang juga merupakan ciri pola kota Hindu-India (Tjahjono dikutip oleh Setyowati,2007:199). Hal tersebut menyimbolkan dominansi pengaruh kraton dalam mengatur perkembangan kota sekaligus keyakinan masyarakat Jawa bahwa Sultan merupakan utusan Tuhan dan kraton merupakan sebuah model dari kerajaan surgawi. Penataan kota-kota tradisional di Jawa berpola konsentrik dapat pula dijelaskan makna simbolisnya menurut konsep mancapat yang menekankan relasi transendental antara dunia makrokosmos (Tuhan, alam semesta, atau buana agung) dengan dunia mikrokosmos. Secara harafiah, mancapat berarti pembagian lima yang kemudian menjadi acuan dalam penataan ruang-ruang arsitektur di kota-kota Jawa (Karsono, 1996:145).

\section{Pola Hubungan antar Ruang}

Bentuk pola ruang Kampung Kauman Yogyakarta dipengaruhi oleh hubungan yang terbentuk antara Masjid, Alun-Alun dan Kraton Yogyakarta melalui sumbu imajiner. AlunAlun dalam tinjauan kosmologi berfungsi sebagai pusat bertemunya elemen Masjid dengan Kraton. Menurut konsep relasi Jawa, beberapa pola hubungan dalam kampg Kauman Yogyakarta merefleksikan:

Pola konsentrik dengan Masjid Agung Kauman Yogyakarta sebagai pusat mengekspresikan kedudukan simbolis Masjid sebagai elemen bermakna penting sekaligus 
sakral. Pola tersebut sekaligus menyimbolkan orientasi pandangan hidup warga Kauman terhadap Tuhan dan nilai-nilai luhur Islam.

Pola linear dengan Masjid sebagai titik orientasi pergerakan publik melalui koridor/jalan utama kampung menyiratkan masih kuatnya orientasi hidup dan pandangan warga setempat terhadap Islam.

Pola sporadik yang terbentuk dari hubungan antar fasilitas keagamaaan (langgar) yang tersebar di penjuru kampung Kauman menyiratkan besarnya pengaruh Islam (keyakinan terhadap Tuhan) dalam perilaku dan budaya hidup sehari-hari warga Kauman.

Sebagaimana halnya Kampung Kauman Yogyakarta, hubungan antar elemen pada ruang Kampung Kauman Semarang menyimbolkan kuatnya keyakinan setempat terhadap nilia-nilai religi. Bangunan Masjid Agung Kauman dan Kompleks Kanjengan (bekas pusat pemerintahan kadipaten) dihubungkan dengan satu area ruang terbuka (bekas Alun-Alun di depan Masjid) melalui sumbu imajiner sebagaimana diatur oleh Kyai Ageng Pandan Arang II sebagai Bupati Kadipaten Kanjengan masa itu. Konsep relasi manusia serta implementasinya pada pola struktur ruang Kampung Kauman Semarang adalah:

1. Pola konsentrik dengan Masjid Agung Kauman Semarang sebagai pusat permukiman mengekspresikan kedudukan simbolis Masjid sebagai elemen bermakna sakral yang sekaligus menyimbolkan orientasi hidup warga Kauman terhadap nilai-nilai luhur Islam.

2. Pola linear dengan Masjid sebagai titik orientasi pergerakan publik melalui desain koridor/jalan utama kampung menyiratkan masih kuatnya orientasi hidup dan pandangan warga setempat terhadap Islam.

3. Pola sporadik yang terbentuk dari hubungan antar berbagai fasilitas umum khususnya perdagangan di seluruh penjuru kampung memperlihatkan orientasi aktivitas sehari-hari warga setempat pada bidang ekonomi. Hal tersebut semakin jelas dirasakan pengaruhnya setelah Pasar Johar dan Pasar Ya'ik terbangun di sekitar permukiman Kauman.

\section{Fungsi Bangunan}

Kampung Kauman Yogyakarta berperan sebagai sentra pendidikan Islam sekaligus sebagai permukiman abdi dalem pamethakan yang memiliki relasi birokrasi politik dengan Kraton Yogyakarta. Relasi antara warga Kauman Yogyakarta dengan pihak penguasa Kraton tetap terpelihara dengan baik yang tercermin dari tetap bertahannya fungsi-fungsi bangunan yang berkaitan erat dengan Kraton. Sedangkan pada konteks Kampung Kauman Semarang, fungsi komersial mendominasi tata guna lahan setempat. Makna fungsi bangunan kampung Kauman Yogyakarta dan Semarang dapat diinterpretasikan:

1. Fungsi fasilitas ibadah melalui Masjid Agung Kauman menyiratkan adanya relasi antara manusia dengan Tuhan sekaligus relasi antara manusia sebagai penguasa (Kraton dan Kadipaten) dengan masyarakat.

2. Fungsi fasilitas ibadah (berupa musholla dan langgar) menyiratkan adanya konsep relasi lokal dengan Tuhan dan orientasi keyakinan terhadap Islam.

3. Fungsi fasilitas pendidikan seperti sekolah, pondok pesantren, fasilitas komersial maupun berbagai fasilitas umum pendukung kawasan memperlihatkan keyakinan lokal terhadap konsep relasi antara manusia dengan masyarakat melalui interaksi sosial yang berlangsung dalam berbagai kegiatan di bidang ekonomi, sosial dan budaya.

4. Fungsi komersial yang mendominasi pola fungsi kampung Kauman Semarang memperlihatnya orientasi pandangan setempat terhadap konsep relasi dirinya dengan masyarakat sekitar maupun dalam konsep relasi pribadi melalui usaha untuk memenuhi kebutuhan hidupnya. Kegiatan perdagangan di sekitar Pasar Johar dan Pasar Ya'ik mendesak permukiman Kauman dan mengancam monumentalitas Masjid Agung Kauman termasuk area kompleks Kanjengan sebagai pusat pemerintahan peninggalan 
masa lampau.

5. Fungsi hunian tetap bertahan mendominasi pola fungsi kampung Kauman Yogyakarta. Hal tersebut menyiratkan orientasi lokal terhadap konsep relasi antara dirinya sebagai pribadi maupun dengan masyarakat sekitar.

6. Fungsi ruang terbuka sebagai wadah inetraksi sosial semakin terdesak pada kasus kampung Kauman Yogyakarta maupun Semarang. Dalam hal ini, konsep relasi manusia dengan alam maupun dalam konteks relasi pribadi dengan masyarakat sekitar terancama punah.

Orientasi konsep relasi manusia dengan Tuhan relatif lebih dominan ditemukan pada kasus kampung Kauman Kauman Yogyakarta dibandingkan pada Kampung Kauman Semarang. Hal tersebut disebabkan oleh:

1. Adanya relasi birokrasi politik antara penguasa Kraton dengan warga Kauman Yogyakarta. Sultan HB I mengatur tanggung jawab warga Kauman setelah ditetapkannya status kampung sebagai daerah perdikan ${ }^{2}$. Tugas abdi dalem pamethakan adalah mengurus seluruh kegiatan keagamaan Kraton serta mengelola Masjid Agung Kauman sebagai Masjid kerajaan.

2. Pembangunan Pasar Johar di sekitar Kampung Kauman Semarang mendesak wilayah permukiman Kauman. Selain itu, tidak adanya relasi politik secara khusus antara penguasa dengan warga Kauman mengakibatkan perkembangan kampung lebih berorientasi pada perdagangan.

\section{Ketinggian Bangunan}

Pada kawasan yang tetap memelihara keberlangsungan nilai-nilai budaya dan kearifan lokalnya, bangunan dengan seluruh aspek pembentuk kualitas desain sebagaimana halnya aspek ketinggian bangunan, dapat menyimbolkan makna dan nilai-nilai tertentu. Berdasarkan konsep relasi dalam pandangan Jawa, ketinggian bangunan yang membentuk struktur ruang kampung Kauman Yogyakarta dan Semarang dapat dijelaskan sebagai berikut:

Masjid Agung Kauman Yogyakarta dengan ketinggian 3 lantai terlihat sebagai elemen paling dominan dalam konteks kawasan sedangkan hunian dibangun dengan ketinggian rata-rata antara 1 (satu) sampai dengan 2 (dua) lantai. Hal tersebut merefleksikan orientasi keyakinan warga Kauman terhadap nilai-nilai Islam. Selain memperlihatkan orientasi lokal terhadap konsep relasi pribadi manusia dengan Tuhan, tercermin pula loyalitas warga setempat yang tetap menjaga kaidah membangun sesuai dengan aturan membangun Kraton. Pengaruh Kraton dalam mengatur pola pembangunan kampung Kauman Yogyakarta memberikan keuntungan bagi tetap terperliharanya monumentalitas Masjid Agung Kauman sebagai simbol pandangan hidup warga Kauman sekaligus simbol kekuasaan politik kerajaan/Kraton.

Masjid Agung Kauman Semarang memiliki ketinggian 3 lantai namun secara hirarkis, dominansi monumentalitas Masjid berkurang akibat dari pembangunan sejumlah pusat perdagangan di sekitar Masjid (Pasar Johar dan Pasar Ya'ik) yang dibangun dengan ketinggian lebih dari 3 (tiga) lantai. Selain pusat perdagangan yang dibangun dengan ketinggian lebih dari 3 (tiga) lantai, sejumlah hunian dan pertokoan dibangun dengan ketinggian lebih dari ketinggian Masjid. Hal tersebut mencerminkan orientasi pandangan warga Kauman Semarang yang lebih dominan ke aspek ekonomi.

${ }^{2}$ Menurut Zahnd (Model Baru Perancangan Kota yang Kontekstual, 2008:93) status daerah perdikan diberikan kepada suatu wilayah dengan membebaskan pembayaran pajak dan sebagai gantinya adalah menerima kewajiban dari warga Kauman dengan menjalankan tugas atau jasa tertentu. Kauman sebagai permukiman para santri bertugas untuk melayani kraton dan kota dalam menjalankan aktivitas keagamaan. 


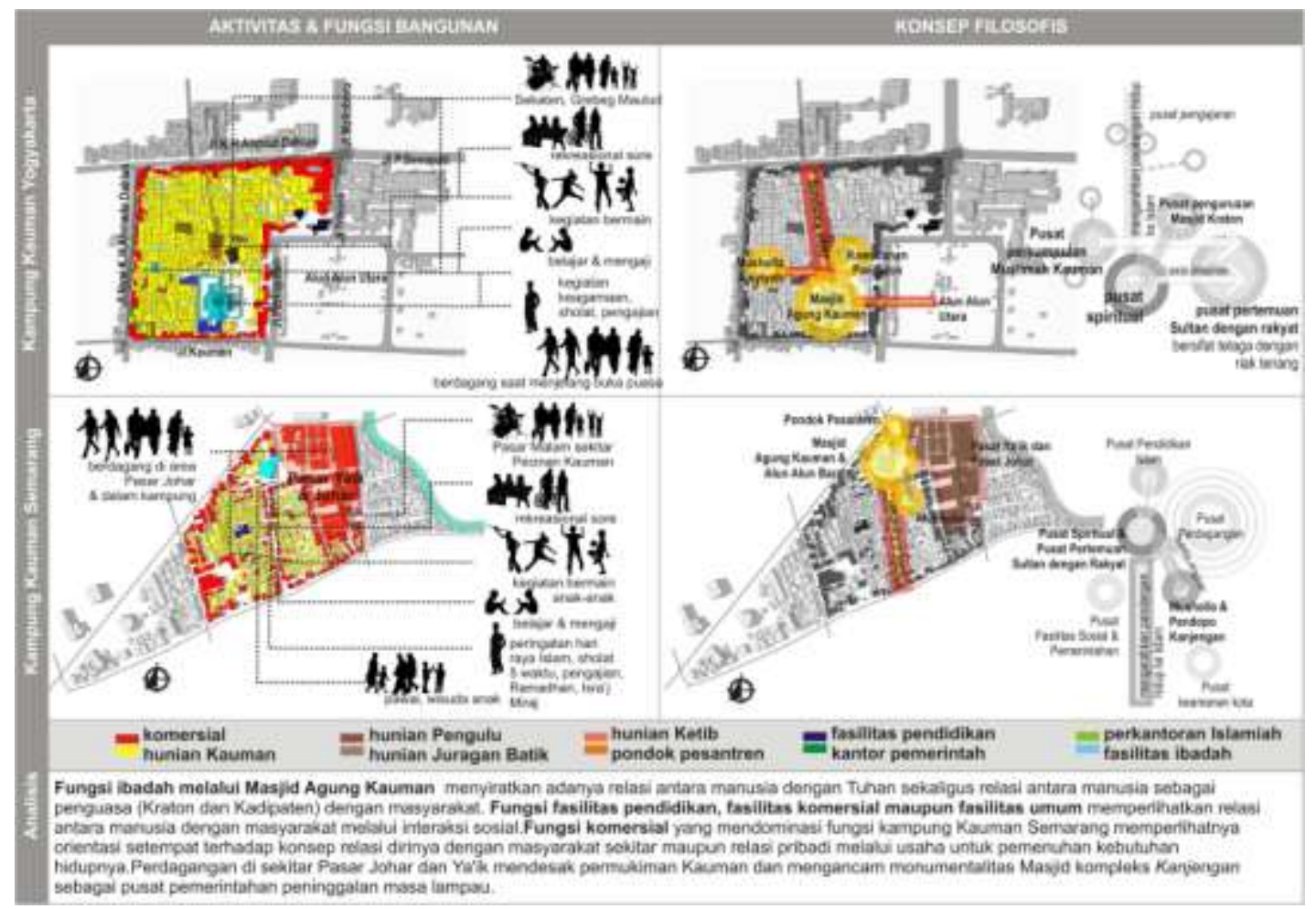

Sumber: Peneliti, 2014

\section{Gambar 2. Manifestasi konsep relasi pada aspek fungsi bangunan Kampung Kauman Yogyakarta dan Semarang}

Orientasi konsep relasi manusia dengan Tuhan relatif lebih dominan ditemukan pada kampung Kauman Kauman Yogyakarta dibandingkan pada Kampung Kauman Semarang dilihat dari aspek ketinggian bangunan. Sebaliknya, konsep relasi manusia dengan masyarakat dan dirinya sebagai sebuah pribadi lebih dominan ditemukan pada kampung Kauman Semarang. Perbedaan karakteristik antara kedua kampung Kauman tersebut dapat disebabkan oleh beberapa faktor, yaitu:

Sebagaimana halnya pada aspek fungsi bangunan, pengaruh Kraton yang turut mengatur pola ketinggian bangunan di kampung Kauman Yogyakarta mengakibatkan tetap terjaganya monumentalitas Masjid Agung Kauman sebagai Masjid kerajaan.

Pada kasus kampung Kauman Semarang, tidak terdapat figur penguasa simbolik yang mengkontrol perkembangan kampung dengan mengikat warga Kauman dalam bentuk delegasi tugas dan tanggung jawab, sebagaimana halnya pada kasus Kauman Yogyakarta dan relasinya dengan pihak Kraton. Pembangunan pusat-pusat perdagangan seperti Pasar Johar dan Pasar Ya'ik termasuk sejumlah hunian dan pertokoan di sekitar Masjid Agung Kauman Semarang yang dibangun melebihi ketinggian Masjid, melemahkan kualitas hirarki dan monumentalitas Masjid Agung Kauman. Hal tersebut merefleksikan dominansi orientasi pandangan warga Kauman Semarang pada konsep relasi manusia dengan kebutuhan pribadinya maupun dengan masyarakat sekitar melalui aktivitas perdagangan. 


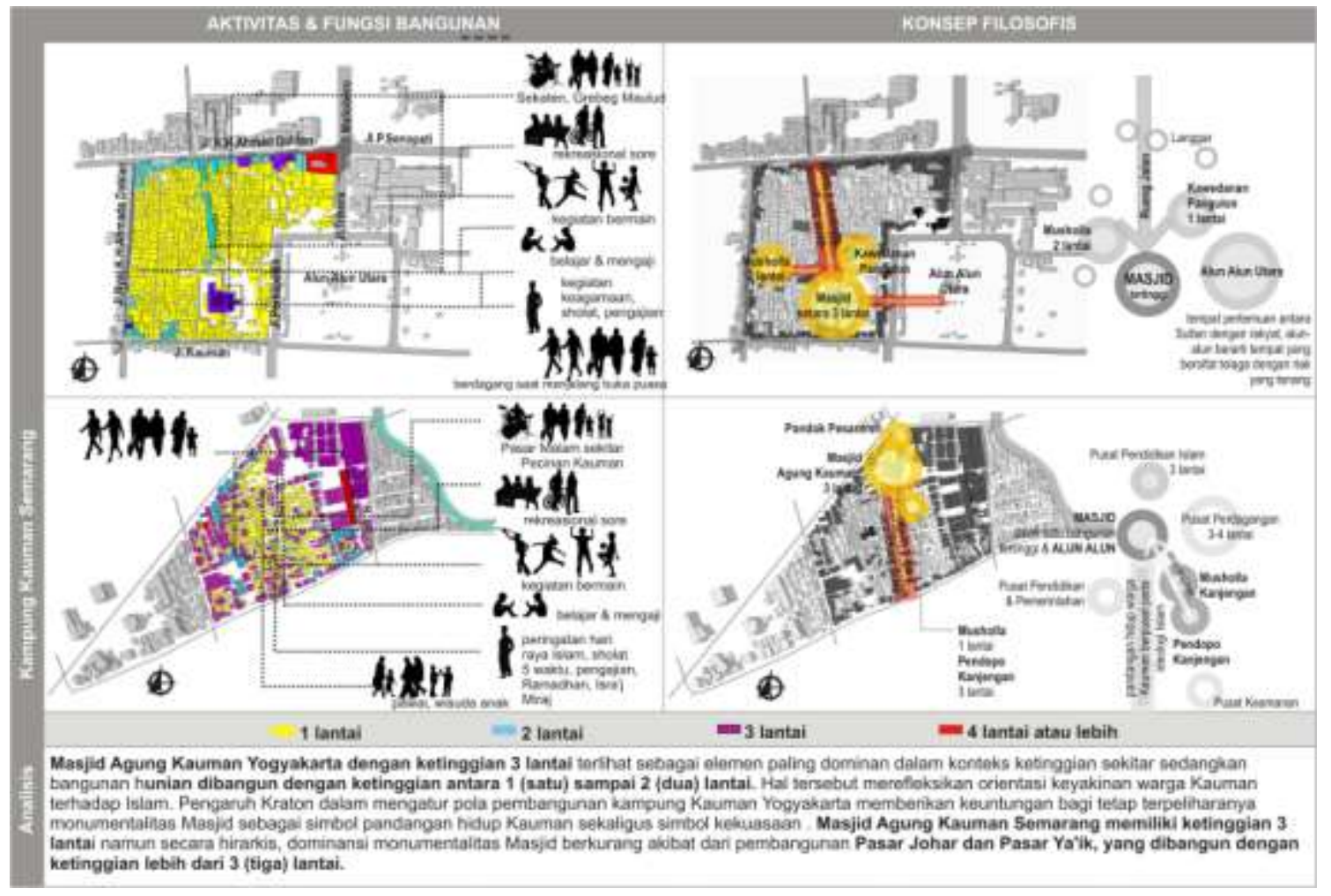

Sumber: Peneliti, 2014

\section{Gambar 2. Manifestasi konsep relasi pada aspek ketinggian bangunan Kampung Kauman Yogyakarta dan Semarang}

\section{Orientasi Bangunan}

Selain aspek fungsi dan ketinggian bangunan, orientasi atau arah hadap bangunan dapat menyimbolkan makna atau nilai filosofis dan keyakinan tertentu. Berkaitan dengan konsep relasi dalam pandangan Jawa, orientasi bangunan pada struktur ruang kampung Kauman Yogyakarta dan Semarang dapat dijelaskan sebagai berikut:

Orientasi bangunan Masjid Agung Kauman Yogyakarta ke arah ruang terbuka AlunAlun dan bertemu dengan Kraton dalam satu garis sumbu imajiner mengadopsi tipologi pembangunan Masjid pada era Mataram Islam. Sultan Hamengku Buwana I memiliki peran sentral dalam menentukan desain bangunan Masjid Agung Kauman sehingga Masjid sekaligus menjadi simbol kekuasaan. Berdasarkan konsep relasi dalam pandangan Jawa, hal tersebut merepresentasikan adanya konsep relasi antara manusia dengan Tuhan, antara manusia (penguasa) dengan masyarakat dan antara manusia dengan alam.

Sedangkan pada kasus Kampung Kauman Semarang, Masjid Agung Kauman berorientasi ke Qiblat/Mekah (sesuai amanat Nabi Muhammad SAW) sehingga merefleksikan keyakinan setempat untuk mengembalikan pandangannya pada kemurnian ajaran Islam (bebas dari pengaruh duniawi/kekuasaan politik) setelah sebelumnya orientasi Masjid Agung Semarang diarahkan pada area Alun-alun. Dalam pandangan Jawa, hal tersebut menyiratkan keyakinan warga Kauman terhadap adanya konsep relasi antara manusia dengan Tuhan.

Orientasi bangunan Kawedanan Pangulon ke arah Masjid Agung Kauman merepresentasikan adanya tanggungjawab khusus pengulu Masjid untuk mengelola Masjid Agung Kauman sebagai masjid utama kerajaan. Hal tersebut berkaitan dengan pelimpahan tugas dan wewenang oleh Sultan HB I kepada warga Kauman yang kemudian berstatus sebagai abdi dalem pamethakan. Sesuai dengan tugas dan tanggung jawabnya, Sultan 
memberikan status daerah perdikan bagi warga Kauman Yogyakarta (Zahnd, 2008:93). Hal tersebut menyimbolkan adanya perwujudan konsep relasi antara manusia dengan Tuhan dan dengan masyarakat sekitar.

Sedangkan pada kasus kampung Kauman Semarang, pengaruh kekuasaan terhadap penataan ruang wilayah disimbolkan oleh pengaturan arah hadap Pendopo Kanjengan ke Alun-Alun. Orientasi bangunan pendopo ke ruang terbuka Alun-alun merefleksikan adanya perwujudan konsep relasi antara manusia dengan alam dan dengan masyarakat sekitar.

Bagaimana konsep relasi dalam pandangan Jawa dimanifestasikan ke tatanan ruang kampung Kauman di Kota Yogyakarta dan Semarang khususnya pada aspek orientasi bangunan, dapat diamati pada gambar 3.

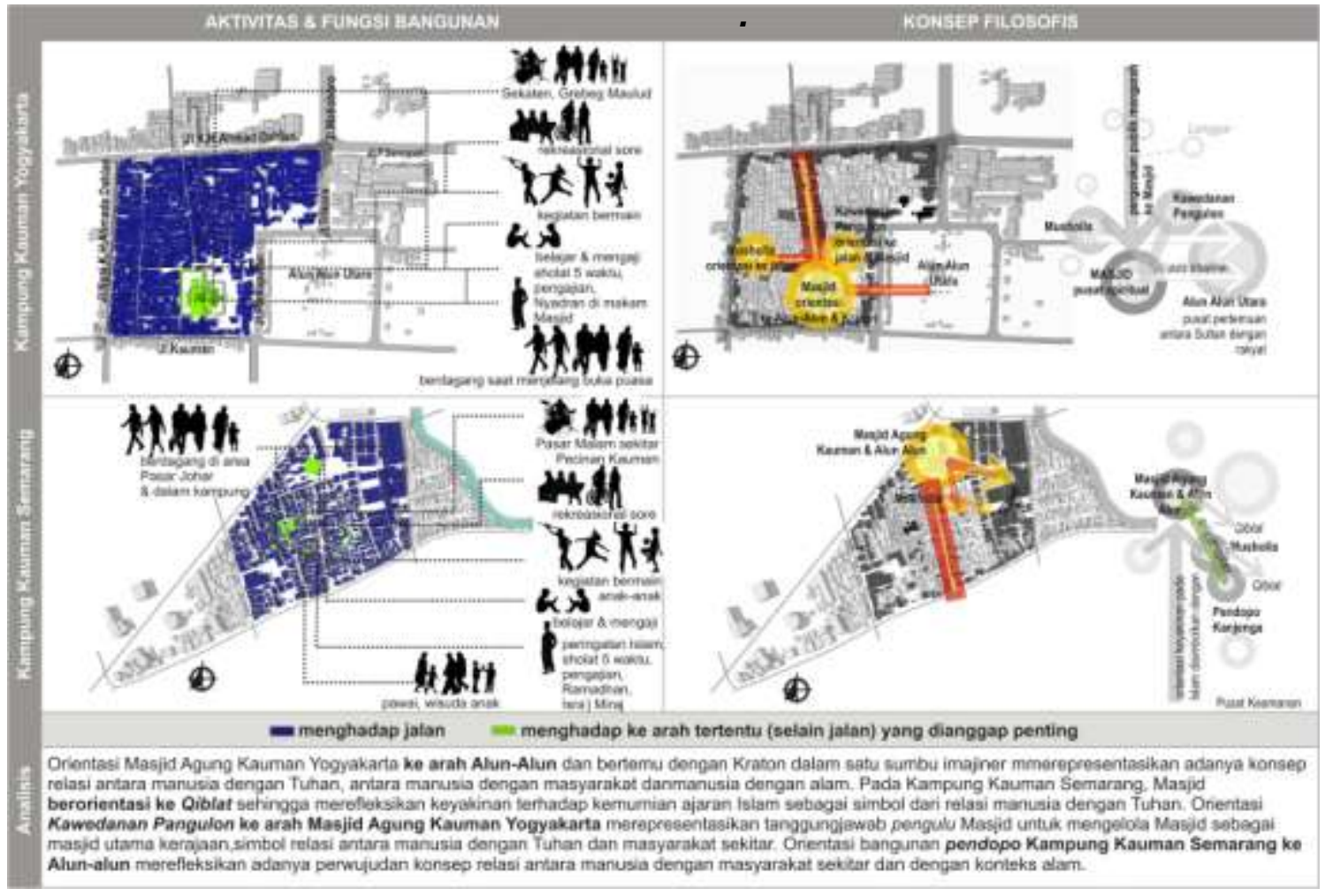

Sumber: Peneliti, 2014

\section{Gambar 3. Manifestasi konsep relasi pada aspek orientasi bangunan Kampung Kauman Yogyakarta dan Semarang}

\section{Hirarki Jalan}

Hirarki atau pembedaan fungsi jalan pada suatu kawasan dapat menyimbolkan satu makna atau keyakinan tertentu khususnya pada kawasan bersejarah dan religius. Berkaitan dengan konsep relasi dalam pandangan Jawa, sistem hirarki jalan pada struktur ruang kampung Kauman Yogyakarta dan Semarang dapat dijelaskan sebagai berikut:

Jalan/akses utama kampung Kauman Yogyakarta secara fisik merepresentasikan fungsinya sebagai wadah pergerakan publik yang menghubungkan antara jalan KHA Dahlan dengan bagian inti kampung. Jalan utama kampung berorientasi langsung ke arah Masjid Agung Kauman sehingga memperlihatkan peran sentral Masjid sebagai pusat pandangan setempat. Pada masa Ramadhan atau saat berbuka puasa, jalan beralih fungsi sebagai koridor perdagangan. Sebagian warga Kauman Yogyakarta memanfaatkan ruang 
jalan untuk menjajakan berbagai jenis makanan minuman selama bulan puasa. Berdasarkan realita tersebut, konsep relasi antara manusia dengan Tuhan, relasi antara manusia dengan alam dan dengan masyarakat sekitar turut dimanifestasikan melalui desain jalan utama kampung yang menghubungkan antara Masjid dengan area sekitar kampung.

Sedangkan pada kasus kampung Kauman Semarang, jalan berfungsi pula sebagai koridor perdagangan selain sebagai wadah pergerakan publik. Jalan bersifat menerus dan terarah langsung ke Masjid Agung Kauman Semarang sehingga memperlihatkan peran simbolik Masjid sebagai pusat keyakinan warga Kauman. Berdasarkan realita tersebut, konsep relasi antara manusia dengan Tuhan, relasi antara manusia dengan alam dan dengan masyarakat sekitar turut dimanifestasikan ke dalam desain jalan utama kampung Kauman Semarang yang menghubungkan antara Masjid dengan area kampung.

Secara kosmologis, terdapat pula garis imajiner yang menghubungkan antara pusat pemerintahan (Kraton dan Kanjengan Semarang), Masjid Agung Kauman dengan ruang terbuka alun-alun. Dalam keyakinan Jawa, alun-alun dianggap mewakili simbol alam yang memiliki sifat sebagaimana ombak yang tenang dan sekaligus sebagai tempat bertemunya Raja dengan seluruh rakyatnya. Garis imajiner yang menghubungkan antara ketiga elemen simbolik ruang kota Yogyakarta dan Semarang, mencerminkan keyakinan lokal terhadap adanya konsep relasi antara manusia dengan Tuhan, antara manusia dengan masyarakat sekitar dan relasi antara manusia dengan alam. Prosesi ritual yang berlangsung terutama pada hari besar keagamaan Islam biasanya memanfaatkan rute yang menghubungkan ketiga elemen simbolik tersebut, misalnya pada upacara Grebeg Maulud Nabi atau Grebeg Agung.

Bagaimana konsep relasi dalam pandangan Jawa dimanifestasikan ke tatanan ruang kampung Kauman di Kota Yogyakarta dan Semarang khususnya pada aspek hirarki jalan, dapat diamati pada gambar 4.

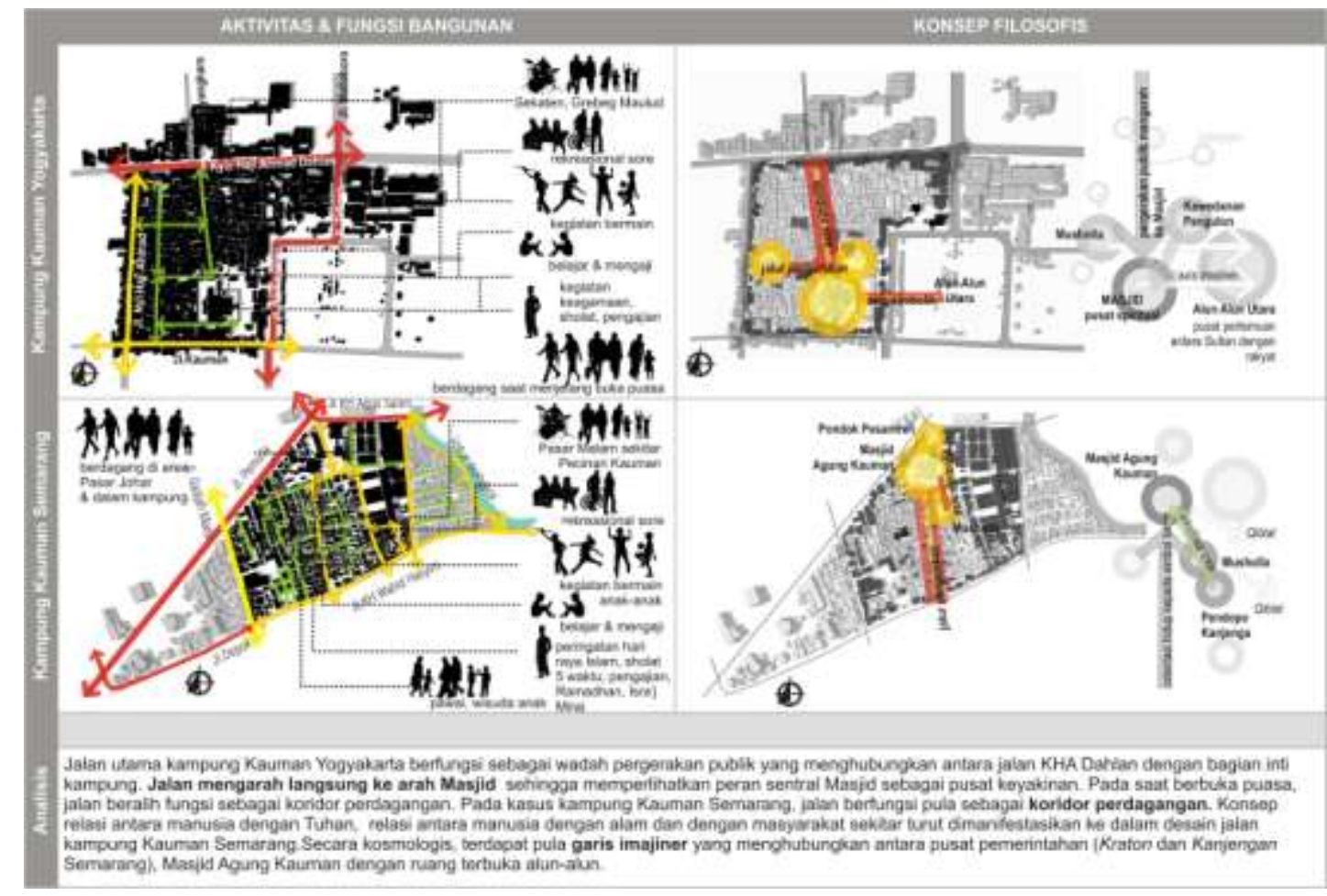

Sumber: Peneliti, 2014

Gambar 4. Manifestasi konsep relasi pada aspek hirarki jalan Kampung Kauman Yogyakarta dan Semarang 


\section{Ruang Terbuka}

Ruang terbuka dapat berperan sebagai simbol makna atau keyakinan khususnya pada kasus kawasan bersejarah dan kawasan religius. Berkaitan dengan konsep relasi dalam pandangan Jawa, ruang terbuka pada struktur ruang kampung Kauman Yogyakarta dan Semarang dapat dijelaskan sebagai berikut:

1. Ruang terbuka berupa area pelataran dan makam pada kompleks Masjid Agung Kauman Yogyakarta berfungsi sebagai pusat aktivitas religi dan budaya. Dalam kehidupan sehari-hari, ruang terbuka pelataran Masjid dimanfaatkan pula sebagai ruang komunal untuk bersosialisasi antar warga. Dengan demikian dapat ditarik kesimpulan bahwa perwujudan konsep relasi antara manusia dengan Tuhan, antara manusia dengan alam, dan antara manusia dengan masyarakat diwujudkan melalui elemen ruang terbuka kampung Kauman Yogyakarta.

2. Ruang terbuka berupa area bekas alun-alun Barat yang terdapat di depan Masjid Agung Kauman Semarang berfungsi sebagai pusat aktivitas perdagangan, religi dan budaya. Dalam perkembangannya, batas-batas fisik Alun-alun Barat telah hilang sehingga terkesan menyatu dengan kompleks Masjid dan kini dimanfaatkan sebagai wadah aktivitas perdagangan. Perubahan pada fisik dan fungsi alun-alun Barat disebabkan oleh besarnya pengaruh pembangunan dari area Pasar Ya'ik dan Pasar Johar yang cenderung tidak terkendali. Ruang terbuka di sekitar pasar umumnya difungsikan pula sebagai ruang parkir dan perdagangan bagi para PKL sehingga ruang terbuka yang tersisa hanya sekitar 15\% dari luas kampung Kauman Semarang. Meskipun pengaruh modernisasi sangat dominan, kekhasan Kauman Semarang berusaha untuk tetap dilestarikan melalui penyelenggaraan upacara keagamaan dan tradisi budaya yang umumnya berpusat di areal ruang terbuka sekitar Masjid Agung Kauman. Berdasarkan realita tersebut, dapat disimpulkan bahwa perwujudan konsep relasi antara manusia dengan Tuhan, antara manusia dengan alam, dan antara manusia dengan masyarakat turut diwujudkan melalui ruang terbuka kampung Kauman Semarang.

3. Ruang terbuka lainnya pada kedua kampung Kauman yang berfungsi sebagai halaman atau pekarangan hunian maupun perkantoran dan bangunan perdagangan semakin berkurang akibat dari meningkatnya kepadatan bangunan di dalam kampung Kauman. Hal tersebut mencerminkan orientasi pandangan warga Kauman Yogyakarta dan Semarang terhadap konsep relasi antara manusia dengan alam yang semakin kabur, namun semakin mengarah pada konsep relasi diri sebagai individu yang berusaha memenuhi kebutuhan pribadi dan keluarganya.

\section{Simpulan}

Pola struktur ruang dengan konfigurasi tertentu akan memberi identitas pada ruang kampung Kauman dan merefleksikan adanya kegiatan budaya yang berlangsung di dalamnya termasuk nilai keyakinan atau pandangan setempat. Berdasarkan hasil analisis terhadap bentuk ruang kampung Kauman di Yogyakarta dan Semarang, dapat disimpulkan bahwa terdapat faktor-faktor yang mempengaruhi terbentuknya struktur ruang kampung Kauman.

Faktor-faktor yang mendasari perbedaan karakteristik antara kedua kampung Kauman dapat dibagi menjadi 2 (dua) kategori,yaitu:

Ideologi Islam yang berkembang di Kampung Kauman Yogyakarta tidak hanya berorientasi pada ajaran Islam namun juga pada kearifan lokal yang telah berlangsung turun temurun. Hal tersebut tercermin dari tradisi budaya yang berlangsung hingga saat ini. Setelah Islam masuk, tradisi leluhur dimodifikasi dengan menambahkan falsafah agama pada setiap ritualnya, misalnya Nyadran yang awalnya ditujukan pada leluhur kini ditujukan kepada Tuhan. Tradisi leluhur yang bertahan di Kampung Kauman Yogyakarta 
disebabkan oleh pengaruh Kraton yang sebagian besar tradisinya berlandaskan pada keyakinan masa lampau.

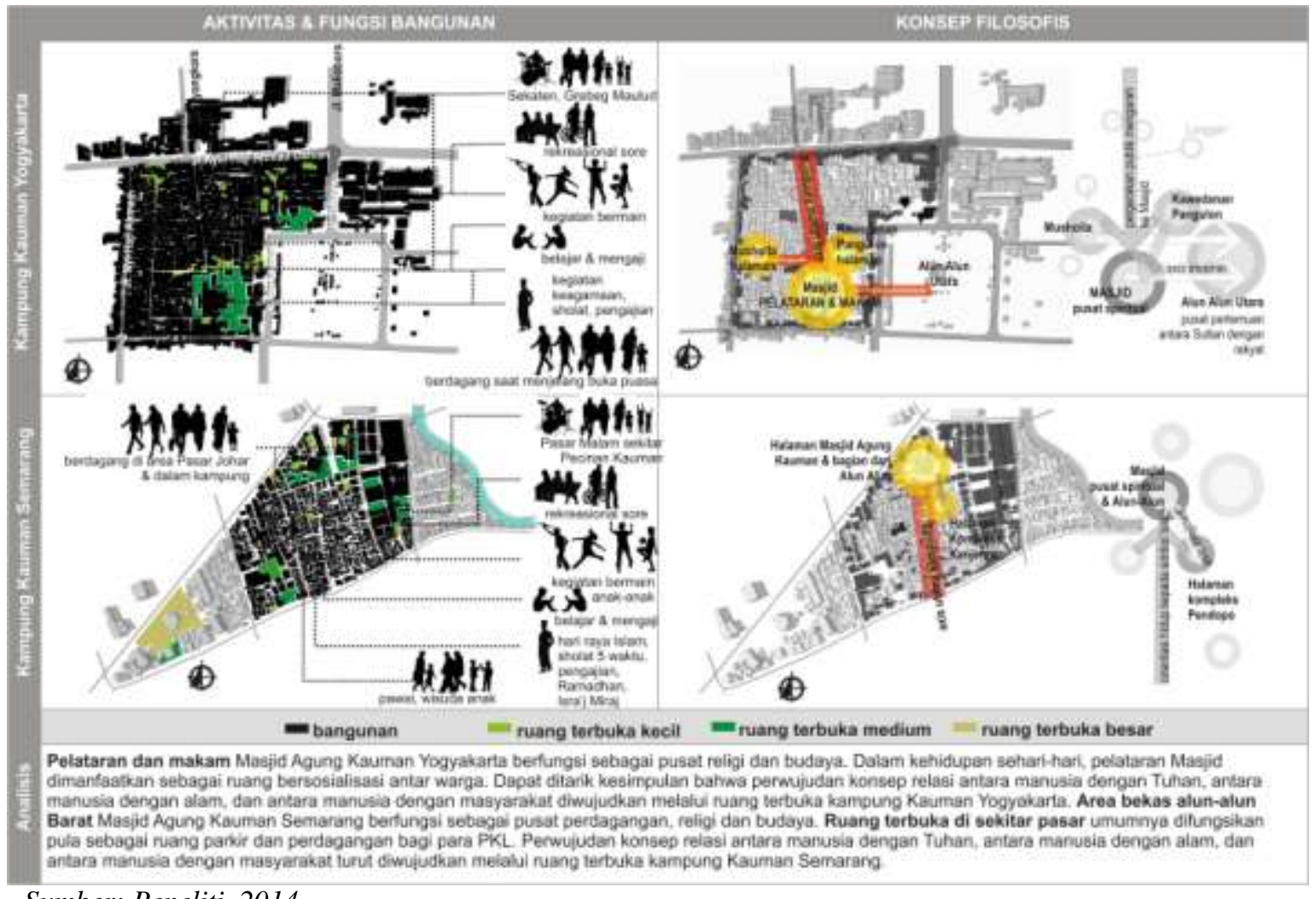

Sumber: Peneliti, 2014

\section{Gambar 5. Manifestasi konsep relasi pada aspek ruang terbuka Kampung Kauman Yogyakarta dan Semarang}

Ideologi Islam yang berkembang di Kampung Kauman Semarang adalah berorientasi pada kemurnian nilai-nilai luhur Islam sesuai ajaran Nabi Muhammad S.A.W. meskipun tradisi setempat yang berkaitan dengan tradisi leluhur masih tetap bertahan. Nilai-nilai modern yang masuk ke dalam sistem kehidupan warga Kauman melalui perdagangan, turut mempengaruhi perkembangan kampung selanjutnya.

\section{Daftar Rujukan}

Bosselmann, P., 2008, Urban Transformation: Understanding City Design and Form, Washington: Island Press.

Karsono, D., 1996, Thesis: Kajian Perubahan Bentuk Tata Ruang Lingkungan Permukiman di Kauman Surakarta, Semarang: UNDIP, Program Pascasarjana Magister Teknik Arsitektur.

Ronald, A., 1988, Manusia dan Rumah Jawa, Penerbit JUTA Yogyakarta.

Setyowati, E., 2007, Karakteristik Ruang Kawasan Dalam Beteng Kraton Yogyakarta, Yogyakarta, UGM: Forum Teknik Volume 30, No. 3, hal.197-272.

Wijanarka, 2001, Teori Desain Kawasan Binaan, Palangkaraya: Universitas Palangkaraya Prodi Teknik Arsitektur.

Wiryomartono, A.B., 1995, Seni Bangunan dan Seni Binakota di Indonesia, Jakarta: PT. Gramedia Pustaka Utama.

Zahnd, M. 2008, Model Baru Perancangan Kota yang Kontekstual, Yogyakarta: PT.Kanisius. 